\title{
Influence of Hospitalization for Cardiovascular Versus Noncardiovascular Reasons on Subsequent Mortality in Patients With Chronic Heart Failure Across the Spectrum of Ejection Fraction
}

\author{
Akshay S. Desai, MD; Brian Claggett, PhD; Marc A. Pfeffer, MD, PhD; Natalie Bello, MD; \\ Peter V. Finn, MD; Christopher B. Granger, MD; John J.V. McMurray, MD; Stuart Pocock, PhD; \\ Karl Swedberg, MD, PhD; Salim Yusuf, MD, D Phil; Scott D. Solomon, MD
}

Background-Noncardiovascular (non-CV) comorbidities may contribute to hospitalizations in patients with heart failure (HF). We examined the incidence of mortality following hospitalization for cardiovascular (CV) versus non-CV reasons in the Candesartan in Heart Failure: Assessment of Reduction in Mortality and Morbidity (CHARM) Program.

Methods and Results - First hospitalizations for CV or non-CV reasons during the CHARM trial (N=7599) were related to subsequent risk of all-cause death using time-updated proportional hazards models. Over median 37.7 month follow-up, 2816 subjects (37.1\%) were not hospitalized, 2893 (38.1\%) were first hospitalized for CV reasons, and 1890 (24.9\%) for non-CV reasons. The death rate (per 100 patient-years) among those not hospitalized was 2.8 compared with 17.8 after CV and 16.5 after non-CV hospitalization (both $P<0.001$ versus not hospitalized). Mortality at 30 days was higher after CV than non-CV hospitalization; however, among 30-day survivors of CV and non-CV hospitalization, rates of subsequent mortality were similar (14.5 versus 14.6 per 100 patient-years; $P=0.62$ ). Rates of $C V$ hospitalization were higher for those with ejection fraction $(\mathrm{EF}) \leq 40 \%$ than those with $\mathrm{EF}>40 \%(P<0.001)$, but rates of non-CV hospitalization did not vary by EF. Low EF patients had higher risk for mortality than preserved EF patients after any hospitalization, but within each EF subgroup, mortality in 30-day survivors of CV versus non-CV hospitalization was similar.

Conclusions-Non-CV hospitalization is frequent in patients with symptomatic heart failure and associated with risk of subsequent mortality similar to CV hospitalization across the spectrum of EF. These findings may have implications for developing strategies to prevent readmissions.

Clinical Trial Registration-URL: http://www.clinicaltrials.gov. Unique identifier: NCT00634309 (CHARM-Added), NCT00634712 (CHARM-Preserved), NCT00634400 (CHARM-Alternative). (Circ Heart Fail. 2014;7:895-902.)

Key Words: heart failure $\boldsymbol{\square}$ hospitalization $\boldsymbol{\square}$ mortality

$\mathrm{H}$ ospitalization is common in patients with heart failure (HF) and is associated with high costs. ${ }^{1,2}$ Despite substantial progress in reducing mortality after HF diagnosis, rates of hospital admission remain high, ${ }^{3}$ and nearly 1 in 4 HF patients is readmitted to hospital within 30 days of discharge. ${ }^{4,5}$ Public and private payors have increasingly targeted readmissions for any reason as a focus of pay-for-performance incentives, ${ }^{6}$ stimulating increasing emphasis on measures to enhance the quality of care transitions and improve longitudinal HF disease management.

\section{Clinical Perspective on p 902}

A large proportion of hospital admissions in HF patients is because of exacerbation of HF and related cardiovascular (CV) conditions, but more than half have been attributed to noncardiovascular (non-CV) causes. ${ }^{1}$ Although hospitalization for HF management is recognized to be associated with a high risk of subsequent mortality, ${ }^{7-9}$ the effect of non$\mathrm{CV}$ hospitalizations on subsequent prognosis is not as well described. We examined the incidence of mortality after first hospitalization for $\mathrm{CV}$ or non- $\mathrm{CV}$ reasons in a broad spectrum of $\mathrm{HF}$ patients enrolled in the Candesartan in Heart Failure: Assessment of Reduction in Mortality and Morbidity (CHARM) program.

Received May 23, 2014; accepted October 8, 2014.

From the Cardiovascular Division, Department of Medicine, Brigham and Women's Hospital, Boston, MA (A.S.D., B.C., M.A.P., N.B., P.V.F., S.D.S.); Cardiology, Duke University, Durham, NC (C.B.G.); Cardiology, Western Infirmary, Glasgow, United Kingdom (J.J.V.M.); Medical Statistics Unit, London School of Hygiene and Tropical Medicine, London, United Kingdom (S.P.); Department of Molecular and Clinical Medicine, Sahlgrenska University Hospital/Östra, Göteborg, Sweden (K.S.); and Population Health Research Institute, McMaster University, Hamilton, ON, Canada (S.Y.).

The Data Supplement is available at http://circheartfailure.ahajournals.org/lookup/suppl/doi:10.1161/CIRCHEARTFAILURE.114.001567/-/DC1.

Correspondence to Akshay S. Desai, MD, MPH, Cardiovascular Division, Brigham and Women's Hospital, 75 Francis St, Boston, MA 02115. E-mail adesai@partners.org

(C) 2014 American Heart Association, Inc.

Circ Heart Fail is available at http://circheartfailure.ahajournals.org 


\section{Methods}

\section{The CHARM Program}

The design and main results of the CHARM Program have been previously reported ${ }^{10-14}$ Briefly, CHARM consisted of 3-component randomized, double-blind, controlled trials comparing candesartan to placebo in 7599 subjects with symptomatic HF (New York Heart Association II-IV) treated with standard HF therapy. The CHARM-Alternative trial (http://www.clinicaltrials.gov, NCT 00634400) enrolled 2028 subjects with left ventricular ejection fraction (EF) $\leq 40 \%$ and previous intolerance of angiotensin-converting enzyme-inhibitors with no requirement for prior hospitalization. The CHARM-Added (NCT 00634309) trial enrolled 2548 subjects with left ventricular EF $\leq 40 \%$ who were treated with an angiotensin-converting enzyme-inhibitor at baseline; to be eligible, those subjects with New York Heart Association II symptoms were required to have a $\mathrm{CV}$ hospitalization within 6 months before randomization. The CHARM-Preserved trial (NCT 00634712) enrolled 3023 subjects with left ventricular EF $>40 \%$, all of whom had a previous history of CV hospitalization. All participating sites obtained approval from local ethics committees or institutional review boards for the conduct of each of the 3-component trials, and all patients gave written informed consent before enrollment. The primary end point for the overall CHARM Program was all-cause mortality, whereas that for each of the component trials was the composite of $\mathrm{CV}$ death or $\mathrm{HF}$ hospitalization. The median follow-up duration for the overall trial was 37.7 months.

Investigators were asked to report all elective and non-elective hospitalizations during study follow-up and to assign the primary reason for each hospitalization to 1 of several predefined CV (worsening HF, hypotension, myocardial infarction, unstable angina, transient ischemic attack, stroke, atrial tachyarrhythmia, ventricular tachyarrhythmia, other) or non-CV (cancer, other) categories. The 8069 hospitalizations assigned to the "other" categories contained free text descriptors of the primary cause that were individually reviewed by an experienced cardiologist (A.S. Desai) and used to design an algorithm reclassify the admission as possible into specific CV (as above) or non-CV categories (gastrointestinal, infectious, orthopedic/ rheumatologic, cancer, renal, pulmonary, endocrine, neurological/ psychiatric, urologic/gynecologic). The specific algorithm and programming code used to perform the reclassification are provided in the Data Supplement.

\section{Statistical Analysis}

The proportion of first hospitalizations attributable to $\mathrm{CV}$ and non- $\mathrm{CV}$ causes was tabulated for the overall CHARM program. Hospitalizations carrying both $\mathrm{CV}$ and non-CV descriptors were assigned to the CV category. Subjects in whom the date of death coincided with the date of the hospitalization were classified as not hospitalized. Baseline characteristics for hospitalized and non-hospitalized patients and for hospitalization by cause were compared using standard chi-squared tests for categorical variables and $t$ tests for continuous variables.

Crude rates of all-cause mortality after first hospitalization for CV or non- $\mathrm{CV}$ reasons were compared in time-updated Cox proportional hazards models. ${ }^{15}$ Adjusted hazard ratios for mortality were also generated after controlling for baseline predictors of all-cause mortality identified in previous CHARM analyses. ${ }^{16}$ Because of the timedependent risk of death associated with hospitalizations and violation of traditional proportional hazards assumptions, death rates were examined within 30 days of incident hospitalization and separately in 30-day survivors of hospitalization to discriminate the effect of nonfatal hospitalization events on subsequent prognosis. Analyses were replicated in subgroups with reduced $(\leq 40 \%)$ and preserved $(>40 \%)$ EF.

To assess the effect of cumulative $\mathrm{CV}$ and non-CV hospitalizations on subsequent prognosis, we compared death rates among the following groups of patients according to their time-updated hospitalization status: those not hospitalized, those hospitalized once for CV or non$\mathrm{CV}$ reasons, and those with $\geq 2$ hospitalizations during the trial. Death rates in those with $\geq 2$ hospitalizations were calculated separately for those whose first 2 hospitalizations were both for $\mathrm{CV}$ reasons, those whose first 2 hospitalizations were both for non-CV reasons, and those with 1 hospitalization of each type.

All analyses were conducted using STATA statistical software (version 13, College Station, TX). The authors (A.S. Desai and B. Claggett) had full access to all the data in the study and take full responsibility for the integrity of the data and the accuracy of the data analysis.

\section{Results \\ Hospitalizations in CHARM-Overall}

Of 7599 subjects enrolled in the CHARM program, 2816 (37.1\%) were not hospitalized during the course of trial followup. Of the remaining 4783 subjects with $\geq 1$ hospitalization, 2893 (38.1\%) were first hospitalized for CV reasons and 1890 (24.9\%) were first hospitalized for non-CV reasons. Among those first hospitalized for CV reasons, hospitalization for HF management accounted for 998 (34.5\%), acute coronary syndromes for $556(19.2 \%)$, arrhythmias for 263 (9.1\%), and stroke/transient ischemic attack for 175 (6.0\%). The most commonly reported specific non-CV causes of first hospitalization were pneumonia/respiratory tract infection, cancer, chronic obstructive pulmonary disease/bronchitis, cholelithiasis/biliary colic, renal failure, anemia, dizziness/vertigo, hyperkalemia, dehydration, and pancreatitis. In aggregate, gastrointestinal, infectious, and orthopedic/rheumatologic problems accounted for nearly half of the first non-CV hospitalizations (Figure 1).

Baseline characteristics according to type of first hospitalization are reported in Tables 1 and 2. Characteristics of the patients who died without hospitalization are separately reported in Table I in the Data Supplement. Hospitalized patients were older with more severe HF and more comorbidities than those who were not hospitalized (Table 1). Patients hospitalized first for CV reasons were similar to those hospitalized first for non-CV reasons, but were younger, had lower $\mathrm{EF}$, and were more commonly men with a prior history of myocardial infarction and angina (Table 2).

\section{Effect of First Hospitalization on Subsequent Mortality}

The crude death rate (per 100 patient-years) among those not hospitalized was 2.8 (95\% confidence interval [CI], 2.63.1) compared with 17.8 (95\% CI, 16.7-19.0) after first CV (relative risk [RR[, 6.3; 95\% CI, 5.5-7.1; $P<0.001$ ) and 16.5 (95\% CI, 15.2-18.0) after first non-CV hospitalization (RR, 5.8; 95\% CI, 5.1-6.6). Mortality within the first 30 days was higher after CV than after non-CV hospitalization (90.4 [95\% CI, 78.8-103.7] versus 55.9 [95\% CI, 45.1-69.2] per 100 patient-years; $P<0.001$ ); however, among 30-day survivors of $\mathrm{CV}$ and non-CV hospitalization, rates of subsequent mortality were similar (14.5 [95\% CI, 13.4-15.6] versus 14.6 [95\% CI, 13.3-16.0] per 100 patient-years; $P=0.85$; Figure 1$)$. The RR for death associated with first $\mathrm{CV}$ and non-CV hospitalization persisted after multivariable adjustment for baseline predictors of mortality, including age, EF, diabetes mellitus, body mass index, New York Heart Association class, sex, smoking, prerandomization history of HF hospitalization, and treatment assignment (adjusted hazard ratio [HR] 6.44 for CV [95\% CI, 5.65-7.33], adjusted HR 6.14 for non-CV [95\% CI, 


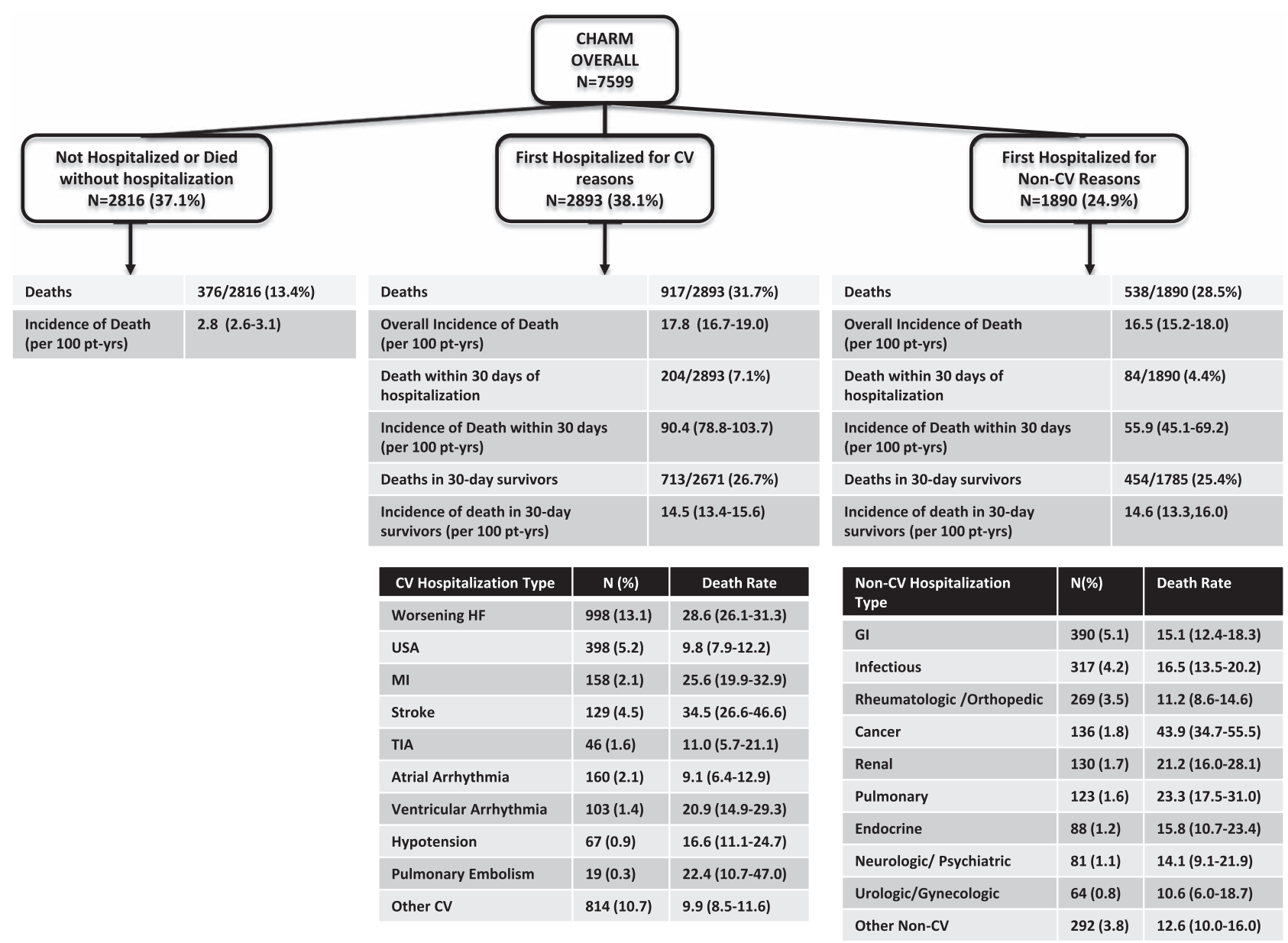

Figure 1. First hospitalizations according to cause and subsequent mortality, Candesartan in Heart Failure: Assessment of Reduction in Mortality and Morbidity (CHARM)-Overall. CV indicates cardiovascular; GI, gastrointestinal; HF, heart failure; MI, myocardial infarction; and TIA, transient ischemic attack.

5.33-7.08]). Further adjustment for country of origin did not substantively alter these findings (results not shown). Among those hospitalized for $\mathrm{CV}$ reasons, death rates were highest for those hospitalized for stroke (34.5 per 100 patient-years; $95 \%$ CI, 26.6-46.6), HF (28.6 per 100 patient-years; 95\% CI, 26.133.3 ), and myocardial infarction (25.6 per 100 patient-years; 95\% CI, 19.9-32.9); among those first hospitalized for nonCV reasons, death rates were highest for cancer (43.9 per 100 patient-years; 95\% CI, 34.7-55.5), pulmonary disease (23.3 per 100 patient-years; 95\% CI, 17.5-31.0), and renal disease (21.2 per 100 patient-years; 95\% CI, 16.0-28.1; Figure 1).

\section{First Hospitalization in Preserved Versus Reduced EF Subgroups}

The incidence of first hospitalization for $\mathrm{CV}$ reasons was higher in patients with $\mathrm{EF} \leq 40 \%$ than those with $\mathrm{EF}>40 \%$ (23.6 versus 19.3 per 100 patient-years; $P<0.001$ ), but the incidence of nonCV hospitalization was similar in both EF subgroups (Table 3). Accordingly, the proportion of first hospitalizations related to non-CV reasons was highest in patients with preserved $\mathrm{EF}$ and declined with lower EF (Figure 2). Among those first hospitalized for $\mathrm{CV}$ reasons, the proportion hospitalized for $\mathrm{HF}$ was lower in patients with $\mathrm{HF}$ and preserved $\mathrm{EF}$ than in those with $\mathrm{HF}$ and reduced $\mathrm{EF}$ (26.8\% versus 38.9\%; $P<0.001)$. Low $\mathrm{EF}$ patients were at higher risk for mortality than high EF patients whether not hospitalized (3.8 versus 1.5 per 100 patient-years; $P<0.001$; $\mathrm{RR}=2.6$; 95\% CI, 1.99-3.27), after CV hospitalization (21.9 versus 11.4 per 100 patient-years; $P<0.001 ; \mathrm{RR}=1.93$; $95 \% \mathrm{CI}, 1.66$ 2.24; adjusted HR, 1.85; 95\% CI, 1.59-2.17), or after non-CV hospitalization (19.4 versus 12.6 per 100 patient-years; $P<0.001$; $\mathrm{RR}=1.54$; 95\% CI, 1.28-1.84; adjusted HR, 1.42; 95\% CI, 1.171.73). However, as for the population as a whole, mortality rates among 30-day survivors of CV and non-CV hospitalization were similar in both EF subgroups (17.6 versus 17.3 per 100 patientyears, $P=0.77$ for $E F \leq 40 \%$; 9.6 versus 11.0 per 100 patient-years, $P=0.22$ for $\mathrm{EF}>40 \%$; Table 3 ). Similar results were apparent in sensitivity analyses restricted to the subset of patients with a history of HF hospitalization before enrollment in the trial, the subset of CHARM-preserved patients with EF $>50 \%$, and the subset of CHARM low EF subjects treated with an angiotensin-converting enzyme-inhibitor and $\beta$-blocker at baseline (Tables II-IV in the Data Supplement).

\section{Cumulative Hospitalizations}

During the course of trial follow-up, a cumulative total of 14740 hospitalizations was recorded in CHARM, including 8965 (60.8\%) for CV reasons and 5775 (39.2\%) for non-CV reasons. Relative to placebo, treatment with candesartan was associated 
Table 1. Baseline Characteristics, CHARM-Overall, According to Incident Hospitalization During Follow-Up

\begin{tabular}{|c|c|c|c|}
\hline & $\begin{array}{c}\text { Any Hospitalization } \\
(\mathrm{N}=4783,62.9 \%)\end{array}$ & $\begin{array}{l}\text { Not Hospitalized } \\
\text { or Death Without } \\
\text { Hospitalization } \\
(\mathrm{N}=2816,37.1 \%)\end{array}$ & $\begin{array}{c}P \text { Value } \\
\text { (Hospitalization vs } \\
\text { No Hospitalization) }\end{array}$ \\
\hline \multicolumn{4}{|l|}{ Patients' characteristics } \\
\hline Age, y, mean (SD) & $66.7(11.0)$ & $63.9(10.9)$ & $<0.0001$ \\
\hline$\geq 75$ & $1284(26.8 \%)$ & $452(16.1 \%)$ & $<0.0001$ \\
\hline Men & $3260(68.2 \%)$ & $1939(68.9 \%)$ & 0.54 \\
\hline \multicolumn{4}{|l|}{ Heart disease risk factors } \\
\hline NYHA class & & & $<0.0001$ \\
\hline$\|$ & $1929(40.3 \%)$ & $1487(52.8 \%)$ & \\
\hline III & $2698(56.4 \%)$ & $1287(45.7 \%)$ & \\
\hline IV & $156(3.3 \%)$ & $42(1.5 \%)$ & \\
\hline LVEF, \%, mean (SD) & $38.4(15.1)$ & $39.7(14.5)$ & $<0.0001$ \\
\hline$<30$ & $1443(30.2 \%)$ & $674(23.9 \%)$ & \\
\hline$\geq 30-39$ & $1355(28.3 \%)$ & $851(30.2 \%)$ & \\
\hline$\geq 40-49$ & $767(16.0 \%)$ & $555(19.7 \%)$ & \\
\hline$\geq 50$ & $1217(25.4 \%)$ & $736(26.1 \%)$ & \\
\hline Heart rate, beats/min, mean (SD) & $73.2(13.1)$ & $72.4(13.0)$ & 0.008 \\
\hline \multicolumn{4}{|l|}{ Blood pressure, mm Hg, mean (SD) } \\
\hline Systolic & $130.3(19.4)$ & $131.8(18.7)$ & 0.001 \\
\hline Diastolic & $75.7(10.8)$ & $78.3(10.5)$ & $<0.0001$ \\
\hline Body mass index, $\mathrm{kg} / \mathrm{m}^{2}$, mean (SD) & $28.2(5.6)$ & $28.3(5.2)$ & 0.09 \\
\hline \multicolumn{4}{|l|}{ Medical history } \\
\hline Prior hospital admission for CHF & $3557(74.4 \%)$ & $1869(66.4 \%)$ & $<0.0001$ \\
\hline Myocardial infarction & $2595(54.2 \%)$ & $1409(50.0 \%)$ & 0.0004 \\
\hline Current angina & $1223(25.6 \%)$ & $585(20.8 \%)$ & $<0.0001$ \\
\hline Stroke & $484(10.1 \%)$ & $179(6.4 \%)$ & $<0.0001$ \\
\hline Diabetes mellitus & $1526(31.9 \%)$ & $637(22.6 \%)$ & $<0.0001$ \\
\hline Hypertension & 2691 (56.3\%) & $1495(53.1 \%)$ & 0.008 \\
\hline Atrial fibrillation & $1468(30.7 \%)$ & $615(21.8 \%)$ & $<0.0001$ \\
\hline Pacemaker & $486(10.2 \%)$ & $151(5.4 \%)$ & $<0.0001$ \\
\hline Current smoker & $697(14.6 \%)$ & $417(14.8 \%)$ & 0.79 \\
\hline $\mathrm{PCl}$ & $825(17.2 \%)$ & $403(14.3 \%)$ & 0.0008 \\
\hline CABG & $1222(25.6 \%)$ & $569(20.2 \%)$ & $<0.0001$ \\
\hline Implantable cardioverter defibrillator & $148(3.1 \%)$ & $43(1.5 \%)$ & $<0.0001$ \\
\hline Previous cancer & $366(7.6 \%)$ & $147(5.2 \%)$ & $<0.0001$ \\
\hline
\end{tabular}

CABG indicates coronary artery bypass graft; CHARM, Candesartan in Heart Failure: Assessment of Reduction in Mortality and Morbidity; CHF, chronic heart failure; LVEF, left ventricular ejection fraction; NYHA, New York Heart Association; and PCl, percutaneous coronary intervention.

with a reduction in total hospitalizations and in the proportion of hospitalizations because of $\mathrm{CV}$ reasons $(58.6 \%$ versus $62.9 \%$ for candesartan versus Placebo; $P<0.001$ ), but treatment did not influence the risk of death after first hospitalization (HR, $0.93 ; 95 \%$ CI, 0.84-1.03; $P=0.146$ ). The detailed breakdown of patients by first and subsequent hospitalization status is reported in Figure 3. Death rates among those hospitalized once for CV reasons were higher than those hospitalized once for non-CV reasons. However, among those with $\geq 2$ hospitalizations, death rates were similar for those whose first 2 hospitalizations were for $\mathrm{CV}$ reasons, those whose first 2 hospitalizations were for non-CV reasons, and those with 1 of each type (Figure 3).

\section{Discussion}

In this population of symptomatic HF patients across broad range of EFs, nearly a third of whom were previously hospitalized for $\mathrm{HF}$ exacerbation, we found that non-CV reasons accounted for nearly $40 \%$ of first hospital admissions. The incidence of non-CV hospitalization was nearly constant across EF categories, whereas that of $\mathrm{CV}$ hospitalization declined with increasing EF; accordingly, the proportion of total admissions attributable to non-CV causes increased with EF. Although the CHARM trial systematically enrolled patients with symptomatic HF, the minority of CV hospitalizations during trial follow-up were related to $\mathrm{HF}$ 
Table 2. Baseline Characteristics, CHARM-Overall, According to Reason for First Hospitalization

\begin{tabular}{|c|c|c|c|}
\hline & $\begin{array}{c}\text { First Hospitalization for } \\
\text { CV Reasons ( } \mathrm{N}=2893,38.1 \%)\end{array}$ & $\begin{array}{c}\text { First Hospitalization for } \\
\text { Non-CV Reasons } \\
(\mathrm{N}=1890,24.9 \%)\end{array}$ & $\begin{array}{c}P \text { Value } \\
\text { (CV vs Non-CV) }\end{array}$ \\
\hline \multicolumn{4}{|l|}{ Patients' characteristics } \\
\hline Age, y, mean (SD) & $66.8(10.9)$ & $67.8(11.0)$ & 0.004 \\
\hline$\geq 75$ & $760(26.3 \%)$ & $524(27.7 \%)$ & 0.27 \\
\hline Men & $2030(70.2 \%)$ & $1230(65.1 \%)$ & 0.0002 \\
\hline \multicolumn{4}{|l|}{ Heart-disease risk factors } \\
\hline NYHA class & & & 0.21 \\
\hline$\|$ & $1161(40.1 \%)$ & $768(40.6 \%)$ & \\
\hline III & $1627(56.2 \%)$ & $1071(56.7 \%)$ & \\
\hline IV & $105(3.6 \%)$ & $51(2.7 \%)$ & \\
\hline LVEF, \%, mean (SD) & $37.6(15.0)$ & $39.5(15.2)$ & $<0.0001$ \\
\hline$<30$ & $926(32.0 \%)$ & $517(27.4 \%)$ & \\
\hline$\geq 30-39$ & $838(29.0 \%)$ & $517(27.4 \%)$ & \\
\hline$\geq 40-49$ & $422(14.6 \%)$ & $345(18.3 \%)$ & \\
\hline$\geq 50$ & $706(24.4 \%)$ & $511(27.0 \%)$ & \\
\hline Heart rate, beats/min, mean (SD) & $73.1(13.4)$ & $73.3(12.6)$ & 0.27 \\
\hline \multicolumn{4}{|l|}{ Blood pressure, mm Hg, mean (SD) } \\
\hline Systolic & $129.8(19.3)$ & $131.1(19.5)$ & 0.03 \\
\hline Diastolic & $75.6(10.8)$ & $75.8(10.8)$ & 0.47 \\
\hline Body mass index, $\mathrm{kg} / \mathrm{m}^{2}$, mean (SD) & $28.1(5.4)$ & $28.4(5.9)$ & 0.12 \\
\hline \multicolumn{4}{|l|}{ Medical history } \\
\hline Prior Hospital admission for CHF & $2144(74.1 \%)$ & $1413(74.8 \%)$ & 0.61 \\
\hline Myocardial infarction & $1650(57.0 \%)$ & $945(50.0 \%)$ & $<0.0001$ \\
\hline Current angina & $817(28.2 \%)$ & $406(21.5 \%)$ & $<0.0001$ \\
\hline Stroke & $300(10.4 \%)$ & $184(9.7 \%)$ & 0.49 \\
\hline Diabetes mellitus & $917(31.7 \%)$ & $609(32.2 \%)$ & 0.70 \\
\hline Hypertension & $1623(56.1 \%)$ & $1068(56.5 \%)$ & 0.79 \\
\hline Atrial fibrillation & $862(29.8 \%)$ & $606(32.1 \%)$ & 0.10 \\
\hline Pacemaker & $307(10.6 \%)$ & $179(9.5 \%)$ & 0.20 \\
\hline Current smoker & $421(14.6 \%)$ & $276(14.6 \%)$ & 0.97 \\
\hline $\mathrm{PCl}$ & $525(18.2 \%)$ & $300(15.9 \%)$ & 0.04 \\
\hline CABG & $755(26.1 \%)$ & $467(24.7 \%)$ & 0.29 \\
\hline Implantable cardioverter defibrillator & $92(3.2 \%)$ & $56(3.0 \%)$ & 0.73 \\
\hline Previous cancer & $200(6.9 \%)$ & $166(8.8 \%)$ & 0.02 \\
\hline
\end{tabular}

CABG indicates coronary artery bypass graft; CHARM, Candesartan in Heart Failure: Assessment of Reduction in Mortality and Morbidity; CHF, chronic heart failure; CV, cardiovascular; LVEF, left ventricular ejection fraction; NYHA, New York Heart Association; and PCl, percutaneous coronary intervention.

exacerbation. Hospitalization for any reason was associated with high risk for subsequent mortality, with higher risk in low than preserved EF patients. Early mortality was higher after first CV than first non-CV hospitalization, but rates of mortality in 30-day survivors were similar in both groups. Cumulative hospitalizations increased the risk of death, but death rates were similar in patients with $\geq 2 \mathrm{CV}$ hospitalizations, $\geq 2$ non-CV hospitalizations, and those with $\geq 1$ of each type.

Non-CV comorbidities, including chronic obstructive pulmonary disease, chronic kidney disease, diabetes mellitus, depression, and dementia, are common in patients with HF and frequently precipitate, contribute to, or complicate $\mathrm{HF}$ exacerbation and the need for hospital admission. ${ }^{17-21}$ The burden of comorbidities seems to be closely linked to the risk for hospital admission, particularly in the elderly and in those with preserved $\mathrm{EF},{ }^{20,22}$ and is an important driver of healthcare costs. $^{23,24}$ In a cross-sectional analysis of 122630 Medicare patients with HF over the age of 65 years, $>80 \%$ of the total inpatient hospital days during follow-up were accounted for by the $40 \%$ of subjects with $\geq 5$ noncardiac comorbidities. ${ }^{20}$ Our data confirms and extends previous data from published registries, ${ }^{25}$ randomized trials, ${ }^{26-28}$ and community dwelling populations, ${ }^{1}$ highlighting the substantial contribution of non-CV hospitalization to the overall burden of hospitalization in HF patients. Notably, patients hospitalized for non-CV 
Table 3. Incidence of Death After First CV or Non-CV Hospitalization, CHARM Overall, and EF Subgroups

\begin{tabular}{|c|c|c|c|c|}
\hline & \multicolumn{2}{|c|}{ LVEF $\leq 40 \%(N=4576)$} & \multicolumn{2}{|c|}{ LVEF >40\% (N=3023) } \\
\hline & $\begin{array}{l}\text { First Hospitalization } \\
\text { for CV Reasons }\end{array}$ & $\begin{array}{l}\text { First Hospitalization for } \\
\text { Non-CV Reasons }\end{array}$ & $\begin{array}{l}\text { First Hospitalization } \\
\text { for CV Reasons }\end{array}$ & $\begin{array}{l}\text { First Hospitalization } \\
\text { for Non-CV Reasons }\end{array}$ \\
\hline Proportion hospitalized & $1842(40.2 \%)$ & $1112(24.3 \%)$ & $1051(34.8 \%)$ & $778(25.7 \%)$ \\
\hline $\begin{array}{l}\text { Incidence of hospitalization } \\
\text { (per } 100 \text { patient-years) }\end{array}$ & $23.6(22.6,24.7)$ & $14.3(13.5,15.2)$ & $19.3(18.2,20.5)$ & $14.3(13.3,15.3)$ \\
\hline Deaths within 30 days of hospitalization & $160 / 1842(8.7 \%)$ & $55 / 1112(5.0 \%)$ & $44 / 1040(4.2 \%)$ & $29 / 778(3.7 \%)$ \\
\hline $\begin{array}{l}\text { Incidence of death within } 30 \text { days } \\
\text { (per } 100 \text { patient-years) }\end{array}$ & $112.4(96.3,131.3)$ & $62.4(47.9,81.3)$ & $52.8(39.3,70.9)$ & $46.6(32.4,67.1)$ \\
\hline Deaths in 30-day survivors & $528 / 1671(31.6 \%)$ & $312 / 1043(29.9 \%)$ & $185 / 1000$ (18.5\%) & $142 / 742(19.1 \%)$ \\
\hline $\begin{array}{l}\text { Incidence of death after } 30 \text { day window (per } 100 \\
\text { patient-years) }\end{array}$ & $17.6(16.2,19.2)$ & $17.3(15.5,19.3)$ & $9.6(8.3,11.1)$ & $11.0(9.3,12.9)$ \\
\hline
\end{tabular}

CHARM indicates Candesartan in Heart Failure: Assessment of Reduction in Mortality and Morbidity; CV, cardiovascular; and LVEF, left ventricular ejection fraction.

reasons were not easily distinguished from those hospitalized for $\mathrm{CV}$ reasons by their demographic or clinical characteristics. As well, these analyses underscore the greater proportionate contribution of non-CV hospitalization to morbidity in those with HF and preserved EF, for whom noncardiac illness may be a particularly important target for therapy. ${ }^{22,29}$

Although unplanned hospitalization for HF management is known to be an important predictor of the risk for subsequent mortality both in $\mathrm{CHARM}^{8}$ and in other populations, ${ }^{7}$ these hospitalizations accounted for fewer than one hird of total hospitalizations recorded during the period of trial follow-up in CHARM. Our analysis is novel in its focus on the prognostic relevance of the balance of non-HF-related hospitalization events. That hospitalization for $\mathrm{CV}$ reasons more generally is associated with poor prognosis, particularly in the early postdischarge interval, is less surprising than the finding that 30-day survivors of non-CV and CV hospitalization have similar rates of subsequent death. There are several potential explanations for the risk associated with non-CV hospitalization in HF patients. First, the need for hospitalization to manage non-CV issues may mark patients with a larger overall burden and severity of medical illness that is itself associated with risk for death in HF patients. Second, exacerbations of comorbidities, such as obstructive lung disease and chronic kidney disease, may directly contribute to worsening HF severity and compromise subsequent outcomes. Finally,

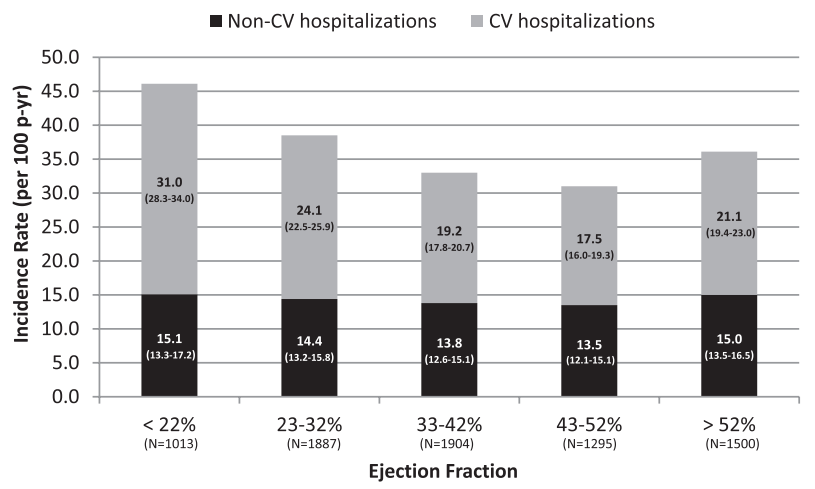

Figure 2. Incidence of first hospitalizations for cardiovascular (CV) and Non-CV Reasons, by ejection fraction. patients with a large burden of comorbidities may be less able to tolerate optimal HF treatement or experience difficulties with adherence to the prescribed medical program.

Whatever the specific explanation, the finding that hospitalization for any cause has similar prognostic relevance in HF patients should draw attention from those interested in improving the quality and reducing the overall costs associated with $\mathrm{HF}$ care. To date, most HF disease management strategies have heavily emphasized appropriate application of guideline-directed medical therapies and aggressive management of filling pressures to relieve congestive symptoms and improve outcomes. Although these strategies are undoubtedly important, such intensive focus on refining the management of a single severe, chronic medical condition may detract from attention to seemingly unrelated conditions that can also powerfully affect subsequent outcomes. ${ }^{30}$ Available data suggests that many non-CV admissions may be related to ambulatory caresensitive conditions and are therefore potentially preventable. ${ }^{20} \mathrm{In}$ this context, inadvertent neglect of comorbid medical illness in HF patients may represent a missed-opportunity for reducing hospital admissions and improving HF care. ${ }^{19}$

Our analysis must be viewed in the context of its limitations. First, we focused on the effect of the first admission during follow-up in CHARM on subsequent prognosis. Because many patients had both $\mathrm{CV}$ and non-CV admissions over the course of trial follow-up, this analysis may be vulnerable to overstating the effect of non-CV admissions on subsequent mortality. However, similar results in the time-varying models exploring the effect of cumulative rates of $\mathrm{CV}$ and non-CV hospitalization suggest that our findings regarding the prognostic relevance of non-CV hospitalization are robust. Second, like all clinical trial populations, patients in CHARM represent a selected population of HF patients, including some previously hospitalized for CV reasons; accordingly, these results may not be generalizable to community HF populations with no prior experience of hospitalization. Finally, because we identified the primary reason for hospitalization based on investigator report, we cannot exclude the possibility that some CV hospitalizations may have been misclassified as non-CV and vice-versa. Although some may challenge our algorithm for categorizing $\mathrm{CV}$ and non-CV hospitalization (see appendix), comparable rates of $\mathrm{CV}$ and non-CV hospitalization reported here from CHARM to those previously 


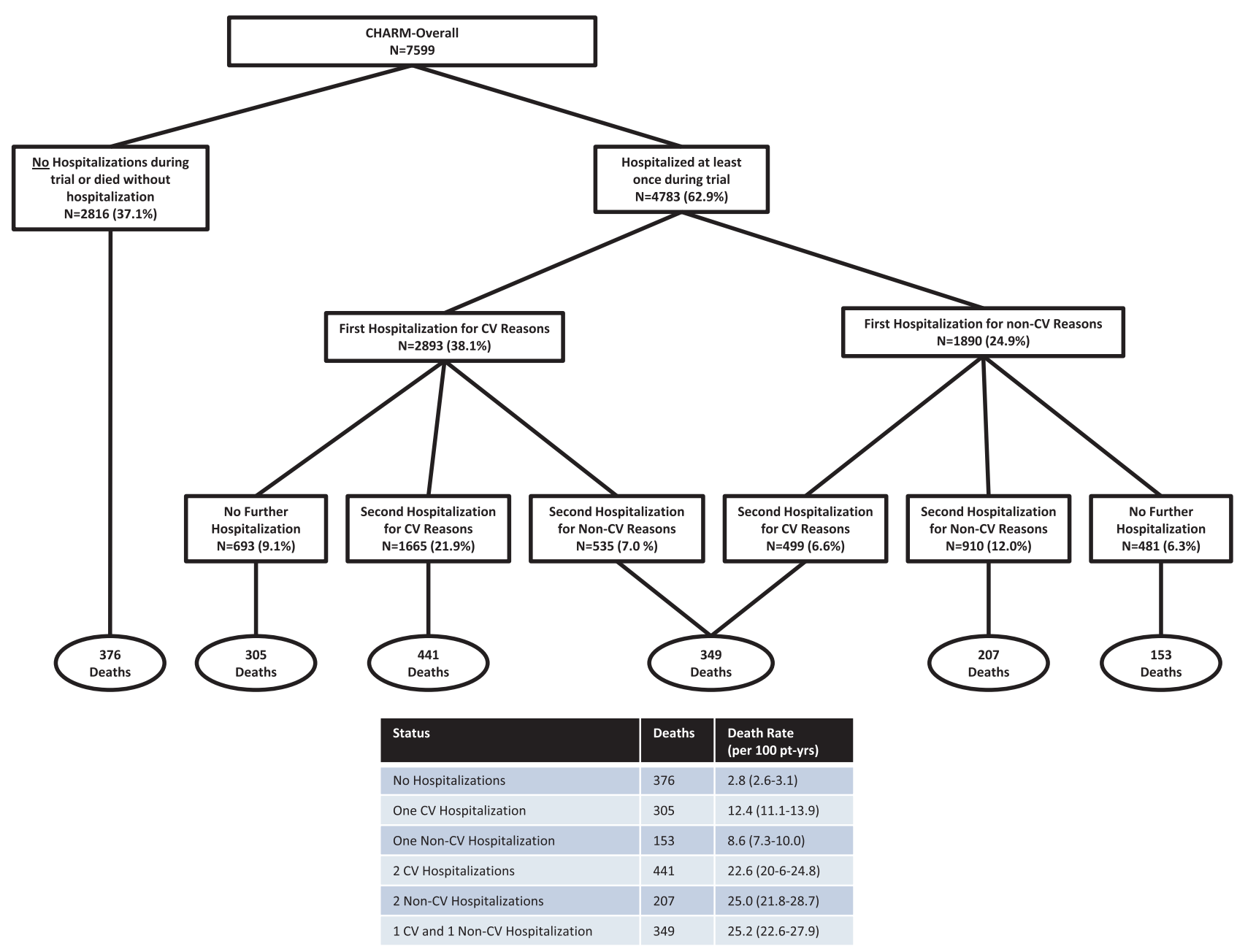

Figure 3. Cumulative hospitalizations during follow-up according to cardiovascular (CV) and non-CV reasons, with associated risk of mortality in time-updated Cox models. CHARM indicates Candesartan in Heart Failure: Assessment of Reduction in Mortality and Morbidity.

reported in other HF populations argue against any systematic error in category assignment.

In summary, we found that a substantial portion of the morbidity and risk of mortality in patients with $\mathrm{HF}$ is related to non-CV hospitalizations. These findings suggest the need for approaches to HF disease management that focus more comprehensively on the treatment of both $\mathrm{CV}$ and non-CV comorbidities, rather than exclusively on HF management. ${ }^{31}$ Though the optimal model for care delivery has yet to be defined, there is increasing evidence to support strategies that leverage the combined expertise of both primary care providers and CV experts. ${ }^{32}$ Embedding HF disease management within integrated care delivery models, such as the patient-centered medical home, may be an important step to making a sustained effect on HF readmission rates.

\section{Sources of Funding}

The CHARM trial was supported by AstraZeneca R\&D, Mölndal, Sweden. The sponsor had no role in the preparation, review, or approval of this article or the decision to submit the article for publication.

\section{Disclosures}

Drs Desai, Claggett, Bello, Finn, Granger, McMurray, Pocock, Swedberg, Yusuf, and Solomon report no financial conflicts relevant to this article. Dr Pfeffer reports previously serving as a consultant and receiving research grants from AstraZeneca, which ended in 2007.

\section{References}

1. Dunlay SM, Redfield MM, Weston SA, Therneau TM, Hall Long K, Shah ND, Roger VL. Hospitalizations after heart failure diagnosis a community perspective. J Am Coll Cardiol. 2009;54:1695-1702.

2. Go AS, Mozaffarian D, Roger VL, Benjamin EJ, Berry JD, Borden WB, Bravata DM, Dai S, Ford ES, Fox CS, Franco S, Fullerton HJ, Gillespie C, Hailpern SM, Heit JA, Howard VJ, Huffman MD, Kissela BM, Kittner SJ, Lackland DT, Lichtman JH, Lisabeth LD, Magid D, Marcus GM, Marelli A, Matchar DB, McGuire DK, Mohler ER, Moy CS, Mussolino ME, Nichol G, Paynter NP, Schreiner PJ, Sorlie PD, Stein J, Turan TN, Virani SS, Wong ND, Woo D, Turner MB; American Heart Association Statistics Committee and Stroke Statistics Subcommittee. Heart disease and stroke statistics-2013 update: a report from the American Heart Association. Circulation. 2013;127:e6-e245.

3. Ross JS, Chen J, Lin Z, Bueno H, Curtis JP, Keenan PS, Normand SL, Schreiner G, Spertus JA, Vidán MT, Wang Y, Wang Y, Krumholz HM. Recent national trends in readmission rates after heart failure hospitalization. Circ Heart Fail. 2010;3:97-103.

4. Krumholz HM, Merrill AR, Schone EM, Schreiner GC, Chen J, Bradley EH, Wang Y, Wang Y, Lin Z, Straube BM, Rapp MT, Normand SL, Drye EE. Patterns of hospital performance in acute myocardial infarction and heart failure 30-day mortality and readmission. Circ Cardiovasc Qual Outcomes. 2009;2:407-413.

5. Joynt KE, Jha AK. Who has higher readmission rates for heart failure, and why? Implications for efforts to improve care using financial incentives. Circ Cardiovasc Qual Outcomes. 2011;4:53-59. 
6. Lindenauer PK, Remus D, Roman S, Rothberg MB, Benjamin EM, Ma A, Bratzler DW. Public reporting and pay for performance in hospital quality improvement. N Engl J Med. 2007;356:486-496.

7. Setoguchi S, Stevenson LW, Schneeweiss S. Repeated hospitalizations predict mortality in the community population with heart failure. Am Heart J. 2007;154:260-266.

8. Solomon SD, Dobson J, Pocock S, Skali H, McMurray JJ, Granger CB, Yusuf S, Swedberg K, Young JB, Michelson EL, Pfeffer MA; Candesartan in Heart failure: Assessment of Reduction in Mortality and morbidity (CHARM) Investigators. Influence of nonfatal hospitalization for heart failure on subsequent mortality in patients with chronic heart failure. Circulation. 2007;116:1482-1487.

9. Abrahamsson P, Swedberg K, Borer JS, Böhm M, Kober L, Komajda M, Lloyd SM, Metra M, Tavazzi L, Ford I. Risk following hospitalization in stable chronic systolic heart failure. Eur J Heart Fail. 2013;15:885-891.

10. Swedberg K, Pfeffer M, Granger C, Held P, McMurray J, Ohlin G, Olofsson B, Ostergren J, Yusuf S. Candesartan in heart failure-assessment of reduction in mortality and morbidity (CHARM): rationale and design. Charm-Programme Investigators. J Card Fail. 1999;5:276-282.

11. Pfeffer MA, Swedberg K, Granger CB, Held P, McMurray JJ, Michelson EL, Olofsson B, Ostergren J, Yusuf S, Pocock S; CHARM Investigators and Committees. Effects of candesartan on mortality and morbidity in patients with chronic heart failure: the CHARM-Overall programme. Lancet. 2003;362:759-766.

12. Granger CB, McMurray JJ, Yusuf S, Held P, Michelson EL, Olofsson B, Ostergren J, Pfeffer MA, Swedberg K; CHARM Investigators and Committees. Effects of candesartan in patients with chronic heart failure and reduced left-ventricular systolic function intolerant to angiotensin-convertingenzyme inhibitors: the CHARM-Alternative trial. Lancet. 2003;362:772-776.

13. McMurray JJ, Ostergren J, Swedberg K, Granger CB, HeldP, Michelson EL, Olofsson B, Yusuf S, Pfeffer MA; CHARM Investigators and Committees. Effects of candesartan in patients with chronic heart failure and reduced left-ventricular systolic function taking angiotensin-converting-enzyme inhibitors: the CHARM-Added trial. Lancet. 2003;362:767-771.

14. Yusuf S, Pfeffer MA, Swedberg K, Granger CB, Held P, McMurray JJ, Michelson EL, Olofsson B, Ostergren J; CHARM Investigators and Committees. Effects of candesartan in patients with chronic heart failure and preserved left-ventricular ejection fraction: the CHARM-Preserved Trial. Lancet. 2003;362:777-781.

15. Altman DG, De Stavola BL. Practical problems in fitting a proportional hazards model to data with updated measurements of the covariates. Stat Med. 1994;13:301-341.

16. Pocock SJ, Wang D, Pfeffer MA, Yusuf S, McMurray JJ, Swedberg KB, Ostergren J, Michelson EL, Pieper KS, Granger CB. Predictors of mortality and morbidity in patients with chronic heart failure. Eur Heart J. 2006;27:65-75.

17. Lang CC, Mancini DM. Non-cardiac comorbidities in chronic heart failure. Heart. 2007;93:665-671.

18. Havranek EP, Masoudi FA, Westfall KA, Wolfe P, Ordin DL, Krumholz HM. Spectrum of heart failure in older patients: results from the National Heart Failure project. Am Heart J. 2002; 143:412-417.

19. Brown AM, Cleland JG. Influence of concomitant disease on patterns of hospitalization in patients with heart failure discharged from Scottish hospitals in 1995. Eur Heart J. 1998;19:1063-1069.
20. Braunstein JB, Anderson GF, Gerstenblith G, Weller W, Niefeld M, Herbert R, Wu AW. Noncardiac comorbidity increases preventable hospitalizations and mortality among Medicare beneficiaries with chronic heart failure. J Am Coll Cardiol. 2003;42:1226-1233.

21. Dahlström U. Frequent non-cardiac comorbidities in patients with chronic heart failure. Eur J Heart Fail. 2005;7:309-316.

22. Shah SJ, Gheorghiade M. Heart failure with preserved ejection fraction: treat now by treating comorbidities. JAMA. 2008;300:431-433.

23. Wang G, Zhang Z, Ayala C, Wall HK, Fang J. Costs of heart failurerelated hospitalizations in patients aged 18 to 64 years. Am J Manag Care. 2010;16:769-776.

24. Dunlay SM, Shah ND, Shi Q, Morlan B, VanHouten H, Long KH, Roger VL. Lifetime costs of medical care after heart failure diagnosis. Circ Cardiovasc Qual Outcomes. 2011;4:68-75.

25. Fang J, Mensah GA, Croft JB, Keenan NL. Heart failure-related hospitalization in the U.S., 1979 to 2004. J Am Coll Cardiol. 2008;52:428-434.

26. O'Connor CM, Miller AB, Blair JE, Konstam MA, Wedge P, Bahit MC, Carson P, Haass M, Hauptman PJ, Metra M, Oren RM, Patten R, Piña I, Roth S, Sackner-Bernstein JD, Traver B, Cook T, Gheorghiade M; Efficacy of Vasopressin Antagonism in heart Failure Outcome Study with Tolvaptan (EVEREST) investigators. Causes of death and rehospitalization in patients hospitalized with worsening heart failure and reduced left ventricular ejection fraction: results from Efficacy of Vasopressin Antagonism in Heart Failure Outcome Study with Tolvaptan (EVEREST) program. Am Heart J. 2010;159:841-849.e1.

27. Kjekshus J, Apetrei E, Barrios V, Böhm M, Cleland JG, Cornel JH, Dunselman P, Fonseca C, Goudev A, Grande P, Gullestad L, Hjalmarson A, Hradec J, Jánosi A, Kamenský G, Komajda M, Korewicki J, Kuusi T, Mach F, Mareev V, McMurray JJ, Ranjith N, Schaufelberger M, Vanhaecke J, van Veldhuisen DJ, Waagstein F, Wedel H, Wikstrand J; CORONA Group. Rosuvastatin in older patients with systolic heart failure. N Engl J Med. 2007;357:2248-2261.

28. Packer M, Fowler MB, Roecker EB, Coats AJ, Katus HA, Krum H, Mohacsi P, Rouleau JL, Tendera M, Staiger C, Holcslaw TL, AmannZalan I, DeMets DL; Carvedilol Prospective Randomized Cumulative Survival (COPERNICUS) Study Group. Effect of carvedilol on the morbidity of patients with severe chronic heart failure: results of the carvedilol prospective randomized cumulative survival (COPERNICUS) study. Circulation. 2002;106:2194-2199.

29. Desai AS. Heart failure with preserved ejection fraction: time for a new approach? J Am Coll Cardiol. 2013;62:272-274.

30. Redelmeier DA, Tan SH, Booth GL. The treatment of unrelated disorders in patients with chronic medical diseases. $N$ Engl J Med. 1998;338:1516-1520.

31. Angermann CE, Störk S, Gelbrich G, Faller H, Jahns R, Frantz S, Loeffler M, Ertl G; Competence Network Heart Failure. Mode of action and effects of standardized collaborative disease management on mortality and morbidity in patients with systolic heart failure: the Interdisciplinary Network for Heart Failure (INH) study. Circ Heart Fail. 2012;5:25-35.

32. Lee DS, Stukel TA, Austin PC, Alter DA, Schull MJ, You JJ, Chong A, Henry D, Tu JV. Improved outcomes with early collaborative care of ambulatory heart failure patients discharged from the emergency department. Circulation. 2010;122:1806-1814.

\section{CLINICAL PERSPECTIVE}

Although many hospital admissions in heart failure patients are caused by exacerbation of heart failure and related cardiovascular (CV) conditions, a large proportion are related to noncardiovascular (non-CV) causes. Hospitalization for heart failure management is known to be associated with high risk for subsequent mortality, but the prognostic implications of non-CV hospitalizations in patients with chronic heart failure are less clear. In this analysis from the CHARM Program, we highlight the important contribution of non-CV hospitalization to morbidity and the risk of mortality in heart failure patients across the spectrum of ejection fraction. Non-CV hospitalization accounted for nearly $40 \%$ of first hospitalizations during the trial, and the proportion of total admissions attributable to non-CV causes increased with ejection fraction. Hospitalization for any reason was associated with high risk for subsequent mortality, with similar death rates in 30-day survivors of both CV and non-CV hospitalization. By underscoring the prognostic importance of non-CV hospitalization, these data suggest the need for approaches to heart failure disease management that focus more comprehensively on the treatment of both CV and non-CV comorbidities, rather than exclusively on heart failure management. As well, because many non-CV hospitalizations may be related to ambulatory care-sensitive conditions, our findings suggest potential to reduce rates of hospital readmission in heart failure patients through greater attention to management of comorbid medical illness. 


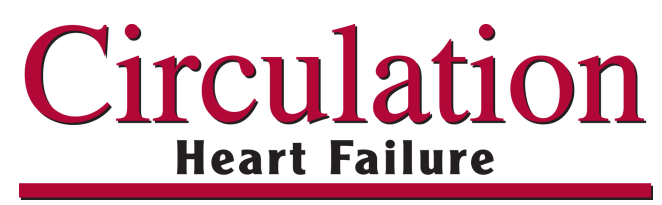

\title{
Influence of Hospitalization for Cardiovascular Versus Noncardiovascular Reasons on Subsequent Mortality in Patients With Chronic Heart Failure Across the Spectrum of Ejection Fraction
}

Akshay S. Desai, Brian Claggett, Marc A. Pfeffer, Natalie Bello, Peter V. Finn, Christopher B.

Granger, John J.V. McMurray, Stuart Pocock, Karl Swedberg, Salim Yusuf and Scott D.

Solomon

Circ Heart Fail. 2014;7:895-902; originally published online October 17, 2014;

doi: 10.1161/CIRCHEARTFAILURE. 114.001567

Circulation: Heart Failure is published by the American Heart Association, 7272 Greenville Avenue, Dallas, TX 75231

Copyright (C) 2014 American Heart Association, Inc. All rights reserved.

Print ISSN: 1941-3289. Online ISSN: 1941-3297

The online version of this article, along with updated information and services, is located on the World Wide Web at:

http://circheartfailure.ahajournals.org/content/7/6/895

Data Supplement (unedited) at:

http://circheartfailure.ahajournals.org/content/suppl/2014/10/17/CIRCHEARTFAILURE.114.001567.DC1

\begin{abstract}
Permissions: Requests for permissions to reproduce figures, tables, or portions of articles originally published in Circulation: Heart Failure can be obtained via RightsLink, a service of the Copyright Clearance Center, not the Editorial Office. Once the online version of the published article for which permission is being requested is located, click Request Permissions in the middle column of the Web page under Services. Further information about this process is available in the Permissions and Rights Question and Answer document.
\end{abstract}

Reprints: Information about reprints can be found online at: http://www.lww.com/reprints

Subscriptions: Information about subscribing to Circulation: Heart Failure is online at: http://circheartfailure.ahajournals.org//subscriptions/ 


\section{SUPPLEMENTAL MATERIAL}

\section{Influence of Hospitalization for Cardiovascular versus Noncardiovascular Reasons on Subsequent Mortality in Patients with Chronic Heart Failure Across the Spectrum of Ejection Fraction}

Desai et al: Non-CV Hospitalization in CHARM

Akshay S. Desai, $\mathrm{MD}^{1}$; Brian Claggett, $\mathrm{PhD}^{1}$; Marc A. Pfeffer, $\mathrm{MD}, \mathrm{PhD}^{1}$; Natalie Bello, $\mathrm{MD}^{1}$;

Peter V. Finn, $\mathrm{MD}^{1}$; Christopher B. Granger, $\mathrm{MD}^{2}$; John J.V. McMurray, MD³

Stuart Pocock, $\mathrm{PhD}^{4}$; Karl Swedberg, MD, $\mathrm{PhD}^{5}$; Salim Yusuf, MD, D Phil ${ }^{6}$;

Scott D. Solomon $\mathrm{MD}^{7}$ 


\section{SUPPLEMENTARY METHODS}

\section{METHODOLOGY FOR CLASSIFICATION OF HOSPITALIZATIONS IN CHARM}

CHARM Investigators were asked to report all elective and non-elective hospitalizations during study follow up and to assign the primary reason for each hospitalization to one of several predefined CV (worsening HF, hypotension, myocardial infarction, unstable angina, transient ischemic attack, stroke, atrial tachyarrhythmia, ventricular tachyarrhythmia, other) or non-CV (cancer, other) categories. 8069 hospitalizations assigned to the 'other' categories contained free text descriptors of the primary cause.

On review by an experienced cardiologist (ASD) of the 'other CV' and 'Other non-CV' hospitalization descriptors, it was clear that a number of events were likely 'misclassified'. We individually reviewed the descriptors for these events to identify a series of free text search strings associated clearly with identifiable ' $\mathrm{CV}$ ' and 'non-CV' causes of hospitalization.

The following search strings were identified as descriptors for ' $\mathrm{CV}$ ' hospitalizations amongst the non-CV category (spelling variations are deliberate):

ischem, ischaem, vascu, arter, ptca, endar, claud, angio, digoxin, digitalis, amioda, angina, aort, ICD, HF, warfa, couma, anticoag, coagul, tachyc, bradyc, tachybrady, hypert, thrombo, atria, afib, defib, bypass, buerg, a-v block, cardiac, carduac, cardio, cordis, heart, gangren, amputat, phelibitis, pacemaker, pace maker, pci, blood clot, DVT, PAD, CAD, IHD, embolism, heart transplan, heart failure, palpitation, mitral, carotid, myocardial, iliac, pericard, poplitea, varicos, ablation, INR, bypass op, by pass op, aneurysm, arrythmia, arrhyth, digitoxicity, electrophysiology, arteriovenous, artenovenous, hypotension, atrio-ventricular, atroventricular, sotalol, beta-blocker, embolectomy, tromboplebitis, trombosis, mesenteric, mesentric, phlebitis, dissociatio AV, vascular op, sick sinus, sinus sick, carotis, atypical c.p, digital infarc, fainting, insufficient circu, peripheral circ, peripheral occlus, volume overload, syncop, synkop, collap, chest pain, chestpain, chest-pain, chest wall pain, thoracal, thoracic, toracic, precordial, chest tight, shortness of breath, s.o.b., dyspn, cabg, coronary, 
pulmonary oed, pulmonary ed, subarac, cerebral infarc, venous inuf, planned pta, ganglia

In addition the following search strings were used to identify non-CV events from the CV category (spelling variations are deliberate):

(Infectious) sepsis, pneumonia, infect, UTI, absces, cellul, endocarditis, septic, erysi, erisi, empy, pyel, pyoderma, cysti, viral, herpes, HIV, AIDS, fever, abcess, angitis, influ, osteomyelitis, febrile, bacter, celllu, clostridium, cholangoitis, purulent

(Endocrine) diab, DM, glyc, glicae, glace, ycae, gluc, thyr, calci, calcemia, iddm, insuli, addison, goitre,goiter

(Pulmonary) lung, pulmo, bronch, copd, chronic obstructive, respiratory, cough, apn, pulmonary fibrosis, pleural effusion, pleuritis, pleura, emphysema, pneumothorax, emoptysis, hyperventilation, asthma, COAD, COPD, C.O.P.D., pneumopat, dispnoe, hypoxia, chronic airways, hydrothorax, hemothorax, hemophtysis, hemoptoea

(Orthopedic/Rheum) gout, arhtrit, arthra, artri, atrit, gatrit, fract, elbow, arthro, hip, lipis, ortho, skelet, rheum, joint, knee, spine, lamin, verteb, rhabdo, spondy, disc, discom, disk, lumba, femur, carpal, karpal, sarcoid, sarkoid, wegeners, polymyosit, osteitis

(Oncologic) cancer, tumor, carci, leukem,leukaem, polycythemia, polycythaemia, monoclonal, myeldysplas, neutropenia, lymphoma, melanoma, clauvicular mass

(Gastrointestinal) abdomin, abdomen, stomac, emesis, intest, digest, pancea, ulcer, ulcus, colic, colon, nausea, rectal, constip, obstip, append, ileus, gastr, gatrit, GI bleed, G-I, melena, melaena, hematemesis, chole, cholitis, diar, pancreatitis, colitis, hepatitis, bowel, duodenitis, dyspep, dyspetic, ercp, gerd, dysphagia, hemorr, haemorr, hernia, hepatic, liver, gall, anus, anal, spleen, appendix, vomit, phagitis, cecum, caecum, jaundice, divertic, divestic, varices, colost, haemirroid, volvul, ascit, polypec, polipec, acsitis, ileitis, ilieus, bilary, biliary, GI, G.I, cirrosis, cirrhosis, rectum, hepato, 
enteritis, colectomy, bile, rectosigm, coloscop, oesophagus, hematemisis, haematomesis, hematochezia, peritonitis, duoden, ascitis, rectocele, oesophagectomy

(Genitourinary) hematuria, haematuria, prosta, urine, urinere, urina, urolith, ureth, urolog, ureter, vagin, gynaeco, hyster, ovar, uterin, metrorrha, bladder, ophor, hydrocele, epidydim, epididim, endometri, epididymitis

(Renal) renal, ranal, kalemia, kaliem, kalaem, kaliamia, kaliaem, kidney, natremia, hyponat, potass, hyperpot, hypovol, azotemia, uremia, uraemia, uramia, electrolyte, neph, dialysis, dehyd, hypo na, hypokalemia, tubular

(Neurologic) seizure, guillain, headache, migra, dizz, vertigo, parkins, numbness, amnesia, depress, psychosis, halluc, anxie, ataxia, vestib, palsy, epilep, enceph, confus, dement, cerebr, subdur, mental, neuro, alzh, alzei, giddi, subsarach, manic, paranoia, coma, myotonic, paresthesia, radiculop, myelopath, deliri, panic, sciatica, walking impaired, aphasia, neuralgia, convulsions, delerium, dilantin, gait, autonomy

(Other Non-CV) general, alco, alchol, sleep, stress, weight, intox, retina, epistax, catara, accident, trauma, alko, anaemia, operation, rehab, unknown, fall, social, fatigue, weakness, malaise, elective, anorexia, etoh, cocaine, suicid, failure to thr, failure to tr, narcotic, myalgia,lipothymia, eczema, obesity, psoriasis, vitrectomy, dental, haematoma, wound, nose, hemoptic, rash, tinni, cheloid hypertrophy

The following decision rules were then applied:

a. For hospitalizations initially classified as "Other CV", the classification was changed to non-CV only if: a) none of the $\mathrm{CV}$ search terms were detected, and b) at least one non-CV search term was detected. For hospitalizations initially classified as "Other non-CV", the classification was changed to 
$\mathrm{CV}$ only if: a) none of the non-CV search terms were detected, and b) at least one CV search term was detected.

b. Events with both $\mathrm{CV}$ and non-CV descriptors were assigned to the $\mathrm{CV}$ category

c. All admissions for chest pain, unless clearly designated 'non-cardiac' were conservatively assigned to the CV category

d. Where possible, $\mathrm{CV}$ and non-CV events were assigned to specific $\mathrm{CV}$ (worsening HF, hypotension, myocardial infarction, unstable angina, transient ischemic attack, stroke, atrial tachyarrhythmia, ventricular tachyarrhythmia, other) and non-CV (gastrointestinal, infectious, orthopedic/rheumatologic, cancer, renal, pulmonary, endocrine, neurologic/psychiatric, urologic/gynecologic) categories. Events were assigned to non-CV categories in a hierarchical fashion to help guide the unique assignment of events that could be allocated to more than one nonCV category.

All events reclassified by this methodology were reviewed by a single investigator (ASD) for errors in category assignment.

Events that were not reclassified were again reviewed to ensure that they could not be assigned to a more specific CV or non-CV category.

The specific programming code used to perform the reclassification is available on request. 
Supplementary Table 1. Baseline Characteristics, CHARM-Overall, according to incident hospitalization during follow up (separating those who died without hospitalization)

\begin{tabular}{|c|c|c|c|c|}
\hline & \multirow{2}{*}{$\begin{array}{c}\text { Any Hospitalization } \\
(\mathrm{N}=4783,62.9 \%)\end{array}$} & \multicolumn{2}{|c|}{ Not Hospitalized (N=2816, 37.1\%) } & \multirow[b]{2}{*}{$\begin{array}{c}\text { p-value } \\
\text { (hosp vs. no hosp) }\end{array}$} \\
\hline & & $\begin{array}{c}\text { Alive, Not } \\
\text { Hospitalized } \\
(\mathrm{N}=2440,32.1 \%)\end{array}$ & $\begin{array}{c}\text { Died without } \\
\text { Hospitalization } \\
(\mathrm{N}=376,4.9 \%)\end{array}$ & \\
\hline \multicolumn{5}{|l|}{ Patients' characteristics } \\
\hline Mean (SD) age (years) & $66.70 \pm 10.96$ & $62.86 \pm 10.84$ & $66.85 \pm 10.62$ & $<0.001$ \\
\hline \begin{tabular}{|l}
$\geq 75$ years \\
\end{tabular} & $1284 \quad(26.8 \%)$ & $355 \quad(14.5 \%)$ & \begin{tabular}{|ll}
98 & $(26.1 \%)$ \\
\end{tabular} & $<0.001$ \\
\hline Men & $3260 \quad(68.2 \%)$ & $1651 \quad(67.7 \%)$ & $288 \quad(76.6 \%)$ & 0.002 \\
\hline \multicolumn{5}{|l|}{ Heart-disease risk factors } \\
\hline NYHA class & & & & $<0.001$ \\
\hline II & $1929 \quad(40.3 \%)$ & $1374 \quad(56.3 \%)$ & $113 \quad(30.1 \%)$ & \\
\hline III & \begin{tabular}{|ll}
2698 & $(56.4 \%)$ \\
\end{tabular} & $1041 \quad(42.7 \%)$ & \begin{tabular}{|ll}
$246 \quad(65.4 \%)$ \\
\end{tabular} & \\
\hline IV & $156 \quad(3.3 \%)$ & $25 \quad(1.0 \%)$ & $17 \quad(4.5 \%)$ & \\
\hline Mean (SD) LVEF (\%) & $38.38 \pm 15.10$ & $40.83 \pm 14.25$ & $32.03 \pm 13.46$ & $<0.001$ \\
\hline EF Categories & & & & $<0.001$ \\
\hline$<30$ & $1443 \quad(30.2 \%)$ & $501 \quad(20.5 \%)$ & $173 \quad(46.0 \%)$ & \\
\hline$\geq 30-39$ & $1355 \quad(28.3 \%)$ & $740 \quad(30.3 \%)$ & $111 \quad(29.5 \%)$ & \\
\hline$\geq 40-49$ & $767 \quad(16.0 \%)$ & $510 \quad(20.9 \%)$ & $45 \quad(12.0 \%)$ & \\
\hline$\geq 50$ & $1217 \quad(25.4 \%)$ & $689 \quad(28.2 \%)$ & $47 \quad(12.5 \%)$ & \\
\hline Mean (SD) heart rate (beats/min) & $73.18 \pm 13.07$ & $72.05 \pm 13.02$ & $74.35 \pm 12.73$ & $<0.001$ \\
\hline \multicolumn{5}{|l|}{ Mean (SD) blood pressure $(\mathrm{mm} \mathrm{Hg})$} \\
\hline Systolic & $130.30 \pm 19.41$ & $132.56 \pm 18.68$ & $127.11 \pm 18.22$ & $<0.001$ \\
\hline Diastolic & $75.66 \pm 10.80$ & $78.73 \pm 10.40$ & $75.45 \pm 10.93$ & $<0.001$ \\
\hline Mean (SD) body-mass index $\left(\mathrm{kg} / \mathrm{m}^{2}\right)$ & $28.21 \pm 5.58$ & $28.49 \pm 5.21$ & $27.35 \pm 4.96$ & $<0.001$ \\
\hline \multicolumn{5}{|l|}{ Medical history } \\
\hline Prior Hospital admission for CHF & $3557 \quad(74.4 \%)$ & $1598 \quad(65.5 \%)$ & $271 \quad(72.1 \%)$ & $<0.001$ \\
\hline Myocardial infarction & $2595 \quad(54.3 \%)$ & $1179 \quad(48.3 \%)$ & $230 \quad(61.2 \%)$ & $<0.001$ \\
\hline Current angina & $1223 \quad(25.6 \%)$ & $500 \quad(20.5 \%)$ & 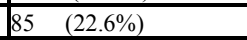 & $<0.001$ \\
\hline Stroke & $484 \quad(10.1 \%)$ & $143 \quad(5.9 \%)$ & \begin{tabular}{|ll}
36 & $(9.6 \%)$ \\
\end{tabular} & $<0.001$ \\
\hline Diabetes mellitus & $1526 \quad(31.9 \%)$ & $\begin{array}{ll}508 & (20.8 \%) \\
\end{array}$ & $129 \quad(34.3 \%)$ & $<0.001$ \\
\hline Hypertension & $2691 \quad(56.3 \%)$ & $1293 \quad(53.0 \%)$ & $202 \quad(53.7 \%)$ & 0.026 \\
\hline Atrial fibrillation & $1468 \quad(30.7 \%)$ & $502 \quad(20.6 \%)$ & $113 \quad(30.1 \%)$ & $<0.001$ \\
\hline Pacemaker & $486 \quad(10.2 \%)$ & $116 \quad(4.8 \%)$ & \begin{tabular}{|ll}
35 & $(9.3 \%)$ \\
\end{tabular} & $<0.001$ \\
\hline Current smoker & $697 \quad(14.6 \%)$ & $355 \quad(14.5 \%)$ & $(16.5 \%)$ & 0.59 \\
\hline PCI & $825 \quad(17.2 \%)$ & $366 \quad(15.0 \%)$ & $(9.8 \%)$ & $<0.001$ \\
\hline CABG & $1222 \quad(25.5 \%)$ & $486 \quad(19.9 \%)$ & $83 \quad(22.1 \%)$ & $<0.001$ \\
\hline Implantable cardioverter defibrillator & $148 \quad(3.1 \%)$ & $39 \quad(1.6 \%)$ & $4 \quad(1.1 \%)$ & $<0.001$ \\
\hline Previous cancer & $366 \quad(7.7 \%)$ & $126 \quad(5.2 \%)$ & $21 \quad(5.6 \%)$ & $<0.001$ \\
\hline
\end{tabular}


Supplementary Table 2. Incidence of Death after first CV or non-CV hospitalization, CHARM overall and EF subgroups, patients with HF hospitalization prior to randomization

\begin{tabular}{|c|c|c|c|c|}
\hline & \multicolumn{2}{|c|}{$\begin{array}{c}\text { LVEF } \leq 40 \% \\
(\mathrm{~N}=3350)\end{array}$} & \multicolumn{2}{|c|}{$\begin{array}{r}\text { LVEF }>40 \% \\
(N=2076)\end{array}$} \\
\hline & $\begin{array}{c}\text { First Hospitalization } \\
\text { for CV Reasons }\end{array}$ & $\begin{array}{l}\text { First Hospitalization } \\
\text { for Non-CV Reasons }\end{array}$ & $\begin{array}{c}\text { First Hospitalization } \\
\text { for CV Reasons }\end{array}$ & $\begin{array}{l}\text { First Hospitalization } \\
\text { for Non-CV Reasons }\end{array}$ \\
\hline $\begin{array}{l}\text { Proportion } \\
\text { Hospitalized }\end{array}$ & $1402(41.9 \%)$ & $864(25.8 \%)$ & $742(35.7 \%)$ & $549(26.4 \%)$ \\
\hline $\begin{array}{l}\text { Incidence of } \\
\text { hospitalization } \\
\text { (per } 100 \text { pt-yrs) }\end{array}$ & $\begin{array}{c}26.1 \\
(24.8,27.5) \\
\end{array}$ & $\begin{array}{c}16.1 \\
(15.1,17.2) \\
\end{array}$ & $\begin{array}{c}20.4 \\
(19.0,21.9) \\
\end{array}$ & $\begin{array}{c}15.1 \\
(13.9,16.4) \\
\end{array}$ \\
\hline $\begin{array}{l}\text { Deaths within } 30 \\
\text { days of } \\
\text { hospitalization }\end{array}$ & $122 / 1402(8.7 \%)$ & $44 / 864(5.1 \%)$ & $31 / 742(4.2 \%)$ & $23 / 549(4.2 \%)$ \\
\hline $\begin{array}{l}\text { Incidence of Death } \\
\text { within } 30 \text { days } \\
\text { (per } 100 \text { pt-yrs) }\end{array}$ & $\begin{array}{c}112.6 \\
(94.3,134.5)\end{array}$ & $\begin{array}{c}64.2 \\
(47.8,86.3)\end{array}$ & $\begin{array}{c}52.5 \\
(36.9,74.7)\end{array}$ & $\begin{array}{c}52.4 \\
(34.8,78.8)\end{array}$ \\
\hline $\begin{array}{l}\text { Deaths in 30-day } \\
\text { survivors }\end{array}$ & $438 / 1274(34.4 \%)$ & $260 / 810(32.1 \%)$ & $154 / 708(21.8 \%)$ & $103 / 524(19.7 \%)$ \\
\hline $\begin{array}{l}\text { Incidence of Death } \\
\text { after } 30 \text { day window } \\
\text { (per } 100 \text { pt-yrs) }\end{array}$ & $\begin{array}{c}19.0 \\
(17.3,20.8)\end{array}$ & $\begin{array}{c}18.4 \\
(16.3,20.8)\end{array}$ & $\begin{array}{c}11.4 \\
(9.7,13.3)\end{array}$ & $\begin{array}{c}11.3 \\
(9.3,13.7)\end{array}$ \\
\hline
\end{tabular}

Supplementary Table 3. Incidence of Death after first CV or non-CV hospitalization, CHARM EF subgroups

\begin{tabular}{|c|c|c|c|c|c|c|}
\hline & \multicolumn{2}{|c|}{$\begin{array}{l}\text { LVEF } \leq 40 \% \\
(N=4576)\end{array}$} & \multicolumn{2}{|c|}{$\begin{array}{r}\text { LVEF }>40 \% \\
(N=3023) \\
\end{array}$} & \multicolumn{2}{|c|}{$\begin{array}{r}\text { LVEF }>50 \% \\
(\mathrm{~N}=1951) \\
\end{array}$} \\
\hline & $\begin{array}{c}\text { First } \\
\text { Hospitalization for } \\
\text { CV Reasons }\end{array}$ & $\begin{array}{c}\text { First } \\
\text { Hospitalization for } \\
\text { Non-CV Reasons }\end{array}$ & $\begin{array}{c}\text { First } \\
\text { Hospitalization } \\
\text { for CV Reasons }\end{array}$ & $\begin{array}{c}\text { First } \\
\text { Hospitalization for } \\
\text { Non-CV Reasons }\end{array}$ & $\begin{array}{c}\text { First } \\
\text { Hospitalization for } \\
\text { CV Reasons }\end{array}$ & $\begin{array}{c}\text { First } \\
\text { Hospitalization for } \\
\text { Non-CV Reasons }\end{array}$ \\
\hline $\begin{array}{l}\text { Proportion } \\
\text { Hospitalized }\end{array}$ & $1842(40.2 \%)$ & $1112(24.3 \%)$ & $1051(34.8 \%)$ & $778(25.7 \%)$ & $705(36.1 \%)$ & $511(26.2 \%)$ \\
\hline $\begin{array}{l}\text { Incidence of } \\
\text { hospitalization } \\
\text { (per } 100 \text { pt-yrs) }\end{array}$ & $\begin{array}{c}23.6 \\
(22.6,24.7)\end{array}$ & $\begin{array}{c}14.3 \\
(13.5,15.2)\end{array}$ & $\begin{array}{c}19.3 \\
(18.2,20.5)\end{array}$ & $\begin{array}{c}14.3 \\
(13.3,15.3)\end{array}$ & $\begin{array}{c}20.5 \\
(19.0,22.1)\end{array}$ & $\begin{array}{c}14.8 \\
(13.6,16.2)\end{array}$ \\
\hline $\begin{array}{l}\text { Deaths within } 30 \\
\text { days of } \\
\text { hospitalization }\end{array}$ & $160 / 1842(8.7 \%)$ & $55 / 1112(5.0 \%)$ & $44 / 1040(4.2 \%)$ & $29 / 778(3.7 \%)$ & $31 / 704(4.4 \%)$ & $21 / 511(4.1 \%)$ \\
\hline $\begin{array}{l}\text { Incidence of Death } \\
\text { within } 30 \text { days } \\
\text { (per } 100 \text { pt-yrs) }\end{array}$ & $\begin{array}{c}112.4 \\
(96.3,131.3)\end{array}$ & $\begin{array}{c}62.4 \\
(47.9,81.3) \\
\end{array}$ & $\begin{array}{c}52.8 \\
(39.3,70.9) \\
\end{array}$ & $\begin{array}{c}46.6 \\
(32.4,67.1) \\
\end{array}$ & $\begin{array}{c}55.5 \\
(39.0,78.9)\end{array}$ & $\begin{array}{c}51.7 \\
(33.7,79.3) \\
\end{array}$ \\
\hline $\begin{array}{l}\text { Deaths in 30-day } \\
\text { survivors }\end{array}$ & $528 / 1671(31.6 \%)$ & $312 / 1043(29.9 \%)$ & $185 / 1000(18.5 \%)$ & $142 / 742(19.1 \%)$ & $126 / 669(18.8 \%)$ & $100 / 484(20.7 \%)$ \\
\hline $\begin{array}{l}\text { Incidence of Death } \\
\text { after } 30 \text { day } \\
\text { window (per } 100 \\
\text { pt-yrs) }\end{array}$ & $\begin{array}{c}17.6 \\
(16.2,19.2)\end{array}$ & $\begin{array}{c}17.3 \\
(15.5,19.3)\end{array}$ & $\begin{array}{c}9.6 \\
(8.3,11.1)\end{array}$ & $\begin{array}{c}11.0 \\
(9.3,12.9)\end{array}$ & $\begin{array}{c}9.8 \\
(8.2,11.7)\end{array}$ & $\begin{array}{c}11.8 \\
(9.7,14.3)\end{array}$ \\
\hline
\end{tabular}


Supplementary Table 4. Incidence of Death after first CV or non-CV hospitalization, CHARM EF subgroups, including those treated with ACE-inhibitor/beta-blocker at baseline

\begin{tabular}{|c|c|c|c|c|c|c|}
\hline & \multicolumn{2}{|c|}{$\begin{array}{l}\text { LVEF } \leq 40 \% \text { on } A C E / \text { Beta-blocker } \\
(\mathrm{N}=1414)\end{array}$} & \multicolumn{2}{|c|}{$\begin{array}{c}\text { LVEF } \leq 40 \% \\
(\mathrm{~N}=4576)\end{array}$} & \multicolumn{2}{|c|}{$\begin{array}{r}\text { LVEF }>40 \% \\
(\mathrm{~N}=3023)\end{array}$} \\
\hline & $\begin{array}{c}\text { First } \\
\text { Hospitalization for } \\
\text { CV Reasons } \\
\end{array}$ & $\begin{array}{c}\text { First } \\
\text { Hospitalization for } \\
\text { Non-CV Reasons } \\
\end{array}$ & $\begin{array}{c}\text { First } \\
\text { Hospitalization for } \\
\text { CV Reasons } \\
\end{array}$ & $\begin{array}{c}\text { First } \\
\text { Hospitalization for } \\
\text { Non-CV Reasons }\end{array}$ & $\begin{array}{c}\text { First } \\
\text { Hospitalization } \\
\text { for CV Reasons } \\
\end{array}$ & $\begin{array}{c}\text { First } \\
\text { Hospitalization for } \\
\text { Non-CV Reasons }\end{array}$ \\
\hline $\begin{array}{l}\text { Proportion } \\
\text { Hospitalized }\end{array}$ & $544(38.5 \%)$ & $370(26.2 \%)$ & $1842(40.2 \%)$ & $1112(24.3 \%)$ & $1051(34.8 \%)$ & $778(25.7 \%)$ \\
\hline $\begin{array}{l}\text { Incidence of } \\
\text { hospitalization } \\
\text { (per 100 pt-yrs) }\end{array}$ & $\begin{array}{c}20.4 \\
(18.7,22.2) \\
\end{array}$ & $\begin{array}{c}13.8 \\
(12.5,15.3) \\
\end{array}$ & $\begin{array}{c}23.6 \\
(22.6,24.7) \\
\end{array}$ & $\begin{array}{c}14.3 \\
(13.5,15.2) \\
\end{array}$ & $\begin{array}{c}19.3 \\
(18.2,20.5) \\
\end{array}$ & $\begin{array}{c}14.3 \\
(13.3,15.3) \\
\end{array}$ \\
\hline $\begin{array}{l}\text { Deaths within } 30 \\
\text { days of } \\
\text { hospitalization }\end{array}$ & $36 / 544(6.6 \%)$ & $21 / 370(5.7 \%)$ & $160 / 1842(8.7 \%)$ & $55 / 1112(5.0 \%)$ & $44 / 1040(4.2 \%)$ & $29 / 778(3.7 \%)$ \\
\hline $\begin{array}{l}\text { Incidence of Death } \\
\text { within } 30 \text { days } \\
\text { (per } 100 \text { pt-yrs) }\end{array}$ & $\begin{array}{c}84.8 \\
(61.1,117.5) \\
\end{array}$ & $\begin{array}{c}71.6 \\
(46.7,109.8) \\
\end{array}$ & $\begin{array}{c}112.4 \\
(96.3,131.3) \\
\end{array}$ & $\begin{array}{c}62.4 \\
(47.9,81.3) \\
\end{array}$ & $\begin{array}{c}52.8 \\
(39.3,70.9) \\
\end{array}$ & $\begin{array}{c}46.6 \\
(32.4,67.1) \\
\end{array}$ \\
\hline $\begin{array}{l}\text { Deaths in 30-day } \\
\text { survivors }\end{array}$ & $123 / 501(24.6 \%)$ & $101 / 345(29.3 \%)$ & $528 / 1671(31.6 \%)$ & $312 / 1043(29.9 \%)$ & $185 / 1000(18.5 \%)$ & $142 / 742(19.1 \%)$ \\
\hline $\begin{array}{l}\text { Incidence of Death } \\
\text { after } 30 \text { day } \\
\text { window (per } 100 \\
\text { pt-yrs) }\end{array}$ & $\begin{array}{c}12.6 \\
(10.5,15.0)\end{array}$ & $\begin{array}{c}16.2 \\
(13.3,19.7)\end{array}$ & $\begin{array}{c}17.6 \\
(16.2,19.2)\end{array}$ & $\begin{array}{c}17.3 \\
(15.5,19.3) \\
\end{array}$ & $\begin{array}{c}9.6 \\
(8.3,11.1) \\
\end{array}$ & $\begin{array}{c}11.0 \\
(9.3,12.9)\end{array}$ \\
\hline
\end{tabular}

